\title{
Role of Granulocyte Oxygen Products in Damage of Schistosoma mansoni Eggs In Vitro
}

\author{
James W. Kazura, Pedro de Brito, John Rabbege, and Masamichi Aikawa \\ Divisions of Geographic Medicine and Hematology/Oncology, Department of Medicine and Institute of Pathology, \\ Case Western Reserve University and University Hospitals, Cleveland, Ohio 44106
}

\begin{abstract}
The objectives of this study were to describe the ultrastructure of granulocyte-Schistosoma mansoni egg interaction and to determine the role of reduced oxygen products as effectors of cell-mediated damage to the parasite target. Granulocytes attached to the parasites and closely applied their plasma membranes to the microspicules of the egg shell $30 \mathrm{~min}$ after mixing in the presence of immune serum. By $4 \mathrm{~h}$, the egg shell was fractured and granulocyte pseudopodia extended toward the underlying miracidium. Granulocyte attachment to eggs resulted in release of $\mathrm{O}_{2}^{-}\left(0.30-0.52 \mathrm{nmol} / \mathrm{min}\right.$ per $2 \times 10^{6}$ cells) and accumulation of $\mathrm{H}_{2} \mathrm{O}_{2}(0.14-0.15 \mathrm{nmol} / \mathrm{min})$ in the presence of antibody or complement. Granulocytes reduced egg tricarboxylic-acid cycle activity and hatching by $28.3 \pm 0.9$ and $35.2 \pm 2.8 \%$, respectively (cell-egg ratio of 1,000 : 1). Exogenous superoxide dismutase $(10 \mu \mathrm{g} / \mathrm{ml})$ inhibited granulocyte toxicity for egg metabolic activity $(3.0 \pm 2.1 \%$ reduction in acetate metabolism vs. $28.3 \pm 0.9 \%$ decrease in controls without superoxide dismutase, $P<0.0005$ ) and hatching (12.5 $\pm 1.8 \%$ reduction, $P<0.0005)$, whereas catalase and heparin had no effect. Inhibitors of myeloperoxidase (1 $\mathrm{mM}$ azide, cyanide, and methimazole) augmented granulocyte-mediated toxicity of egg tricarboxylic-acid cycle activity (44-58\% reduction in activity vs. 31 and 35\% reduction in controls), suggesting that $\mathrm{H}_{2} \mathrm{O}_{2}$ released from cells was degraded before reaching the target miracidium. Oxidants generated by acetaldehyde $(2 \mathrm{mM})$-xanthine oxidase $(10 \mathrm{mU} / \mathrm{ml})$ also decreased egg metabolic activity and hatching by $62.0 \pm 9.0$ and $38.7 \pm 7.3 \%$, respectively. Egg damage by the cell-free system was partially prevented by superoxide dismutase $(26.5 \pm 4.2 \%$ reduction in egg tricarboxylic-acid cycle activity) and completely blocked by catalase ( $0 \%$ reduction in activity). These data suggest that granulocyte-mediated toxicity for $S$. mansoni eggs is dependent on release of $\mathrm{O}_{2}^{-}$or related molecules. These oxygen products, unlike $\mathrm{H}_{2} \mathrm{O}_{2}$, may readily reach the target miracidium where they may be converted to $\mathrm{H}_{2} \mathrm{O}_{2}$ or other microbicidal effector molecules.
\end{abstract}

\section{Introduction}

Attachment of granulocytes (PMN) ${ }^{1}$ to ligand-coated noningestible surfaces may result in cellular spreading, activation of

Received for publication 23 January 1984 and in revised form 10 December 1984.

1. Abbreviations used in this paper: A, absorbance; fIHS, fresh immune human serum; fNHS, fresh normal human serum; GPO, glutathione

J. Clin. Invest.

(c) The American Society for Clinical Investigation, Inc.

0021-9738/85/04/1297/11 $\$ 1.00$

Volume 75, April 1985, 1297-1307 the respiratory burst, and secretion of lysosomal contents. This process has been referred to as "frustrated phagocytosis" and may have physiologic relevance in eosinophil- and neutrophilmediated host defense against infections by multicellular organisms (1-6). Eosinophils are a major component of the granulomatous response around Schistosoma mansoni eggs and are involved in eliminating this parasite stage from host tissues $(7,8)$. Destruction of parasite ova is clearly important to the host as the morbid complications of schistosomiasis mansoni (hepatosplenomegaly and portal hypertension) are largely related to the granulomatous and fibrotic responses to eggs deposited in the liver (9).

$S$. mansoni eggs represent a formidable target for PMN and mononuclear cells. Unlike the lipid-rich outer membranes of unicellular microbes (10) or the syncytium-bound schistosomula (11), the surface of schistosome ova consists of a hard "tanned" proteinaceous shell with multiple pores and microspicules (12-14). Within the shell but not in direct physical contact with mammalian tissues is the live miracidium, which releases enzymes and antigens $(15,16)$. To damage the enclosed miracidium, host effector mechanisms must either physically breach the hard egg shell and/or deliver toxic products outside the shell in areas removed from their possible target. In this situation, effective PMN microbicidal activity may require the generation of high concentrations of toxic mediators or the release of small amounts of these substances over a long period of time. We have recently developed an in vitro assay to assess the biologically relevant effects of human PMN on $S$. mansoni ova (17). Mixed granulocyte preparations or purified neutrophils and eosinophils were found to significantly impair energy metabolism (apparent tricarboxylic-acid cycle activity) of ova in a dose-dependent manner (dimunition of egg metabolic activity was observed at cell-egg ratios of 100:1 and 1,000:1 but not at a 1:1 ratio); hatching of eggs (release of miracidia) was also reduced. These alterations were associated with a diminished capacity of eggs to induce delayed-type hypersensitivity granulomas in vivo.

The purposes of the present study are to delineate the ultrastructural features of the interaction of schistosome eggs and human granulocytes and define the biochemical basis of the deleterious effect of PMN on eggs. Our results indicate that neutrophils and eosinophils initially attach to the outer surface of the egg shell and interdigitate their plasma membranes with the parasite's microspicules. By $4 \mathrm{~h}$ of incubation, this interaction results in fracture of the entire thickness of the shell and the development of PMN pseudopodia that project toward the enclosed miracidium. PMN-egg contact is associated

peroxidase; hilHS, heat-inactivated immune human serum; hiNHS, heat-inactivated normal human serum; PMA, phorbol myristate acetate; PMN, granulocytes; SOD, superoxide dismutase; TCA, tricarboxylic acid. 
with extracellular release of $\mathrm{O}_{2}^{-}$and $\mathrm{H}_{2} \mathrm{O}_{2}$. Damage to ova by $\mathrm{PMN}$ is decreased by exogenous superoxide dismutase (SOD) and unaffected by catalase or heparin. Hydrogen peroxide $\left(\mathrm{H}_{2} \mathrm{O}_{2}\right)$ and oxygen products derived from acetaldehyde-xanthine oxidase also reduce egg tricarboxylic acid cycle activity and hatching; SOD and catalase inhibit the deleterious effects of acetaldehyde-xanthine oxidase on eggs. Inhibitors of myeloperoxidase (azide, cyanide, and methimazole) augment PMNmediated egg damage, suggesting that $\mathrm{H}_{2} \mathrm{O}_{2}$ released from adherent leukocytes is degraded by a peroxidase-catalyzed reaction before reaching the target miracidium. Granulocyte host defense against schistosome ova may thus be dependent on PMN release of superoxide $\left(\mathrm{O}_{2}^{-}\right)$. This molecule, unlike $\mathrm{H}_{2} \mathrm{O}_{2}$, may readily proceed past the egg shell and reach the viable miracidium, where it can be converted to $\mathrm{H}_{2} \mathrm{O}_{2}$ or other microbicidal oxygen species.

\section{Methods}

Isolation of S. mansoni eggs. Parasite eggs were obtained from the livers and intestines of CF1 mice (Carworth Farms, New City, NY) infected with 200 cercariae of $S$. mansoni 8 wk earlier (18). Freshly dissected organs were perfused with cold $\left(4^{\circ} \mathrm{C}\right) 1.7 \% \mathrm{NaCl}$ containing penicillin $(200 \mathrm{U} / \mathrm{ml})$ and streptomycin $(200 \mu \mathrm{g} / \mathrm{ml})(\mathrm{KC}$ Biologicals, Lenexa, KS) and macerated in a blender (Waring Products Div., Dynamics Corp. of America, New Hartford, CT). The resulting suspension was digested for $2 \mathrm{~h}$ at $37^{\circ} \mathrm{C}$ in $0.5 \%$ trypsin (Sigma Chemical Co., St. Louis, MO) and sieved through a sterile Brown capsule (19). The partially purified eggs were layered over $40 \mathrm{ml}$ of a Percoll solution (Sigma Chemical Co.) prepared by mixing one part of stock Percoll with one part of $1.7 \% \mathrm{NaCl}$. After sedimentation by gravity for 10 min, the pellet containing $S$. mansoni eggs free of cellular debris was washed and eggs were enumerated. The percentage of mature eggs was determined according to the method described by Pellegrino et al. (20). Preparations containing $>85 \%$ mature eggs (i.e., eggs with a fully developed miracidium) were washed three times in RPMI 1640 (Gibco Laboratories, Grand Island, NY) containing $200 \mathrm{U} / \mathrm{ml}$ of penicillin, $200 \mu \mathrm{g} / \mathrm{ml}$ of streptomycin, $25 \mathrm{mM}$ Hepes buffer (Sigma Chemical Co.), and $2 \mathrm{mM} \mathrm{L-glutamine} \mathrm{(KC} \mathrm{Biologicals)} \mathrm{(complete} \mathrm{medium)} \mathrm{and}$ suspended to the desired concentration in complete medium or Hanks' balanced salt solution without phenol red (HBSS) (Gibco Laboratories).

In some experiments, miracidia were obtained by exposure of freshly isolated eggs to spring water for $\mathbf{3 0} \mathrm{min}$. Miracidia, intact eggs, and empty shells were visualized with a dissecting microscope; groups of each were separated and aspirated with a Pasteur pipette. Miracidia, "empty" egg shells, and intact eggs were then suspended to $5 \times 10^{3}$ per $4 \mathrm{ml}$ of complete medium and assays of $\left[2-{ }^{14} \mathrm{C}\right]$ acetate metabolism were performed as described below.

Preparation of leukocytes. Blood was obtained from normal donors with no exposure to $S$. mansoni and anticoagulated with $10 \mathrm{U}$ heparin/ ml (Upjohn Co., Kalamazoo, MI). Mixed granulocyte populations were prepared by density gradient centrifugation over Ficoll-Hypaque (Pharmacia Fine Chemicals, Piscataway, NJ) followed by dextran sedimentation (Sigma Chemical Co.) and hypotonic lysis of erythrocytes (21). The purified granulocyte preparations were washed three times in HBSS without $\mathrm{Ca}^{++}$and $\mathrm{Mg}^{++}$(Gibco Laboratories) and suspended to the desired concentration in complete medium or in $\mathrm{Ca}^{++}-\mathrm{Mg}^{++}$ replete HBSS (Gibco Laboratories). Cell counts were performed with a counter (Coulter Electronics Inc., Hialeah, FL). Viability in each of the preparations was $>95 \%$ as judged by exclusion of trypan blue.

Electron microscopy. Eggs $\left(2 \times 10^{3}\right)$ with or without PMN $\left(2 \times 10^{6}\right)$ and $2 \%$ heat-inactivated immune or normal serum were incubated together at $37^{\circ} \mathrm{C}$ for $30 \mathrm{~min}, 2,4$, and $18 \mathrm{~h}$. The preparations were then washed three times in $0.9 \% \mathrm{NaCl}$, fixed in a solution of $0.1 \mathrm{M}$ cacodylate buffer containing $2.5 \%$ glutaraldehyde and $4 \%$ sucrose, and postfixed in $1 \%$ osmium tetroxide. Samples were then dehydrated and embedded in Epon 812 (22). The resulting blocks were cut with a Porter-Blum MT-2 ultramicrotome with a diamond knife (DuPont Instruments-Sorvall Biomedical Div., Newtown, CT). Sections $1 \mu \mathrm{m}$ thick were stained with $1 \%$ toluidine blue and studied by light microscopy to select proper areas for electron microscopy. Thin sections mounted on 200-mesh copper grids and stained with $1 \%$ uranyl acetate and lead citrate were examined with a 100 electron microscope (Elmiskop; Siemens Corp., Iselin, NJ).

$\mathrm{O}_{2}^{-}$and $\mathrm{H}_{2} \mathrm{O}_{2}$ release from ova-stimulated granulocytes. Triplicate preparations of $2 \times 10^{6} \mathrm{PMN}$ were mixed with $2 \times 10^{3} \mathrm{~S}$. mansoni eggs in round-bottomed borosilicate tubes (T1285-3, American Scientific Products Div., American Hospital Supply Corp., McGaw Park, IL) or 5-ml polypropylene tubes (No. 14-956-10, Fisher Scientific Co., Pittsburgh, PA) containing $1.2 \mathrm{mg}$ of cytochrome $c$ (Sigma Chemical Co.) with or without $10 \mu \mathrm{g}$ of SOD (Sigma Chemical Co.) in $1 \mathrm{ml}$ of HBSS. Human serum in a final concentration of $2 \%$ was added from the following sources: (a) heat-inactivated normal serum (hiNHS); $(b)$ heat-inactivated pooled immune serum (hilHS) (obtained from Brazilians or Kenyans with documented $S$. mansoni infection); (c) fresh normal serum (fNHS); or (d) fresh immune serum (fIHS). The cellparasite-serum mixtures were incubated for $0-30 \mathrm{~min}$ at $37^{\circ} \mathrm{C}$ in a Dubnoff shaker, transferred to cuvettes, and SOD-inhibitable reduction of ferricytochrome $c$ was measured at $37^{\circ} \mathrm{C}$ for $10 \mathrm{~min}$ at $1-\mathrm{min}$ intervals in a spectrophotometer (DU-8; Beckman Instruments, Inc., Fullerton, CA) (23). A constant rate of SOD-inhibitable reduction of cytochrome $c$ was observed after 2 min of incubation in the cuvette and continued for an additional $8 \mathrm{~min}$. The rate of extracellular $\mathrm{O}_{2}^{-}$ release was calculated from this value and expressed as $\mathrm{nmol} \mathrm{O}_{2}^{-} / \mathrm{min}$ per $2 \times 10^{6}$ cells, unless otherwise indicated. To determine the efficiency of various concentrations of cytochrome $c$ in measuring $\mathrm{O}_{2}^{-}$release, $0.6,1.2,2.4$, and $3.6 \mathrm{mg}$ of cytochrome $/ \mathrm{ml}$ were used in preliminary experiments (24). More cytochrome $c$ was also added after the initial 10 -min determination of $\mathrm{O}_{2}^{-}$release to ascertain whether a sufficient amount of cytochrome was included in the original mixture to scavenge all the $\mathrm{O}_{2}^{-}$generated.

Phorbol myristate acetate (PMA) $(0.1 \mu \mathrm{g} / \mathrm{ml})$ (Consolidated Midland Corp., Brewster, NY) diluted in dimethyl sulfoxide (Sigma Chemical Co.) was added after the 10 -min measurement of $\mathrm{O}_{2}^{-}$production to determine the capacity of cells to respond to further stimulation of $\mathrm{O}_{2}^{-}$production. This value was compared with $\mathrm{O}_{2}^{-}$production by a similar number of cells not mixed with eggs.

To assess whether the detected $\mathrm{O}_{2}^{-}$was released from PMN adherent to eggs and/or from cells remaining unattached, PMN with eggs attached were separated from nonadherent PMN. PMN $\left(10^{7}\right)$-egg $(5$ $\times 10^{3}$ ) mixtures with $2 \%$ fNHS plus $2 \%$ hilHS were prepared, incubated at $37^{\circ} \mathrm{C}$ for $10 \mathrm{~min}$, and eggs were separated from PMN by allowing the mixtures to settle for an additional $10 \mathrm{~min}$ at $4^{\circ} \mathrm{C}$. The upper 0.9 $\mathrm{ml}$ (primarily containing PMN without eggs) and lower $0.1 \mathrm{ml}$ (primarily containing eggs, with and without adherent PMN) were separated, washed three times in HBSS, and finally placed in $1 \mathrm{ml}$ of HBSS containing $1.2 \mathrm{mg}$ of cytochrome $c / \mathrm{ml}$ with or without $10 \mu \mathrm{g}$ of SOD/ $\mathrm{ml}$. Cytochrome $c$ reduction at 10,30 , and $60 \mathrm{~min}$ was determined and the results were expressed as nanomoles of $\mathrm{O}_{2}^{-}$generated/2 $\times 10^{6}$ cells for each time interval.

To determine the ability of soluble factors derived from egg-serum mixtures to induce release of $\mathrm{O}_{2}^{-}$by PMN, $5 \times 10^{3}$ ova and $2 \%$ sera (from the various sources indicated above) were incubated together for $18 \mathrm{~h}$. Supernatants were harvested and 10,50 , or $100 \mu \mathrm{l}$ was added to PMN before measurement of ferricytochrome $c$ reduction.

Extracellular release of $\mathrm{H}_{2} \mathrm{O}_{2}$ by $\mathrm{PMN}$ was measured by the scopoletin method (25) using an Aminco-Bowman spectrofluorometer (American Instrument Co., Travenol Laboratories, Silver Spring, MD). Cells $\left(2 \times 10^{6}\right)$ and eggs $\left(2 \times 10^{3}\right)$ were incubated in $1 \mathrm{ml}$ of HBSS with $2 \%$ serum (same sources used for the $\mathrm{O}_{2}^{-}$assay) in round-bottomed borosilicate tubes for $10 \mathrm{~min}$ in a shaking water bath held at a temperature of $37^{\circ} \mathrm{C}$. The cell-egg mixtures were then washed in excess 
cold $\left(4^{\circ} \mathrm{C}\right) \mathrm{HBSS}$ and the rate of $\mathrm{H}_{2} \mathrm{O}_{2}$ accumulation was determined as previously described (4).

Assays of PMN-induced egg damage. Damage to $S$. mansoni eggs was assessed by $(a)$ the level of tricarboxylic acid (TCA) cycle activity, (b) release of miracidia (hatching), and (c) capacity to induce granulomas in vivo. An index of TCA cycle activity was obtained by determining the amount of ${ }^{14} \mathrm{CO}_{2}$ generated from $\left[2-{ }^{14} \mathrm{C}\right]$ acetate $(17,26,27)$. In studies of PMN-induced alterations in egg metabolism, triplicate samples of eggs $\left(5 \times 10^{3}\right)$, PMN $\left(5 \times 10^{6}\right)$, and PMN-egg mixtures (all containing $2 \%$ hilHS) were incubated in 10-ml Erlenmeyer flasks containing $4 \mathrm{ml}$ of complete medium to which $2 \mu \mathrm{Ci}$ of $\left[2-{ }^{14} \mathrm{C}\right]$ acetate (sp act $30 \mathrm{mCi} / \mathrm{mmol}$, New England Nuclear, Boston, MA) was added. The flasks were fitted with an airtight rubber stopper and center well (Kontes Co., Vineland, NJ) containing a piece of electrofocusing paper (LKB Produkter, Uppsala, Sweden) $60 \mathrm{~mm}^{2}$. After $24 \mathrm{~h}$ of incubation at $37^{\circ} \mathrm{C}, 0.1 \mathrm{ml}$ of NCS tissue solubilizer (Amersham Corp., Arlington Heights, IL) and $1 \mathrm{ml}$ of $10 \%$ trichloroacetic acid (Sigma Chemical Co.) were respectively injected into the center well and main flask. The flasks were stored for $6 \mathrm{~h}$ at $37^{\circ} \mathrm{C}$, the papers were then removed and placed in $2 \mathrm{ml}$ of scintillant fluid (ACS, aqueous counting scintillant; Amersham Corp.). Samples were left overnight before counting the evolved ${ }^{14} \mathrm{CO}_{2}$ in a liquid scintillation counter (Nuclear Chicago, Chicago, IL). Results were expressed as the percentage of reduction of TCA cycle activity for eggs mixed with PMN compared with eggs incubated alone and calculated with the formula: \% reduction in predicted egg ${ }^{14} \mathrm{CO}_{2}$ generation $=[\mathrm{cpm}($ cells $)+\mathrm{cpm}($ eggs $)-\mathrm{cpm}$ (cells + eggs) $] /[\mathrm{cpm}($ cells $)+\mathrm{cpm}($ eggs) $] \times 100$. Three preparations of catalase $(5,000 \mathrm{U} / \mathrm{ml})$ (Sigma Chemical Corp.; Worthington Biochemical Corp., Freehold, NJ; Calbiochem-Behring Corp., LaJolla, CA), SOD $(10 \mu \mathrm{g} / \mathrm{ml})$ (Sigma Chemical Co.), or heparin (preservativefree, $500 \mathrm{U} / \mathrm{ml}$ ) (Sigma Chemical Co.) were used in some experiments to evaluate their effects on PMN-induced alterations of egg $\left[2-{ }^{14} \mathrm{C}\right]$ acetate metabolism. The enzymatic activity of each catalase preparation was determined by its ability to degrade $\mathrm{H}_{2} \mathrm{O}_{2}(28)$. Sodium azide, sodium cyanide, or methimazole $(1 \mathrm{mM})$ (Sigma Chemical Co.) were also added to PMN-egg mixtures to determine whether inhibition of myeloperoxidase affected PMN-induced changes in egg acetate metabolism (29).

Hatching was determined by exposing eggs to light for $1 \mathrm{~h}$; four drops of $1 \%$ aqueous iodine were then added to stop hatching. Eggs were sedimented at $100 \mathrm{~g} \times 5 \mathrm{~min}$, resuspended in $0.15 \mathrm{M} \mathrm{NaCl}$, and transferred to a Sedgewick-Rafter chamber (Curtin-Matheson, Cleveland, $\mathrm{OH})$ for light microscopic inspection. 200 miracidia and eggs were counted to determine the hatching rate (percentage of eggs that released a miracidium).

For measurements of in vivo granuloma formation, aliquots of eggs were incubated with $\mathrm{H}_{2} \mathrm{O}_{2}$ or acetaldehyde-xanthine oxidase for $24 \mathrm{~h}$ (see below), washed three times in complete medium, suspended to 2,000 in $0.5 \mathrm{ml}$ of $0.15 \mathrm{M} \mathrm{NaCl}$, and injected intravenously into CF1 mice. At $8 \mathrm{~d}$, animals were sacrificed, and their lungs were removed and processed for determining granuloma area with a $\pi \mathrm{Mc}$ particle measurement computer (Millipore Corp., Bedford, MA) (30).

Effects of oxidant-generating systems and scavengers on egg viability. The effects of $\mathrm{H}_{2} \mathrm{O}_{2}$ on egg TCA cycle activity and hatching were determined by addition of reagent $\mathrm{H}_{2} \mathrm{O}_{2}$ (Fisher Scientific Co., Fairlawn, $\mathrm{NJ})$. The concentration of $\mathrm{H}_{2} \mathrm{O}_{2}$ was measured with a spectrophotometer with $\epsilon_{230}=81 \mathrm{M}^{-1} \mathrm{~cm}^{-1}(31)$. To assess the toxicity of $\mathrm{H}_{2} \mathrm{O}_{2}, \mathrm{O}_{2}^{-}$, $\mathrm{OH}^{\prime}$, and possibly ${ }^{~} \mathrm{O}_{2}$, acetaldehyde $(2.0 \mathrm{mM})$ (Eastman Kodak Co., Rochester, NY) and xanthine oxidase $(10 \mathrm{mU} / \mathrm{ml})$ (type II, Sigma Chemical Co.) were incubated with $5 \times 10^{3}$ eggs for $18 \mathrm{~h}$ at $37^{\circ} \mathrm{C}$ in studies of TCA cycle activity (32). The hatching rate of eggs was determined after exposure to acetaldehyde-xanthine oxidase for 2,6 , 18,24 , and $48 \mathrm{~h}$. The rate of $\mathrm{O}_{2}^{-}$generation for this substrate and enzyme was measured by the SOD-inhibitable reduction of ferricytochrome $c$. The effect of degradative enzymes or inhibitors of oxidants generated by acetaldehyde-xanthine oxidase was also evaluated. $\mathrm{H}_{2} \mathrm{O}_{2}$ and $\mathrm{O}_{2}^{-}$were destroyed by the addition of catalase $(5,000 \mathrm{U} / \mathrm{ml})$ and
SOD $(10 \mu \mathrm{g} / \mathrm{ml})$, respectively. The parasite cytotoxic effects of $\mathrm{OH}^{\circ}$ and ${ }^{1} \mathrm{O}_{2}$ were investigated by addition of diazobicyclooctane (Aldrich Chemical Co., Milwaukee, WI), mannitol, sodium benzoate, or histidine (all from Sigma Chemical Co.) $(33,34)$.

Determination of SOD, catalase, and glutathione peroxidase activities in $S$. mansoni eggs. Ova were isolated as described above, suspended in $0.1 \mathrm{M}$ phosphate-buffered saline $(\mathrm{pH} 7)$ containing $0.1 \%$ Triton $\mathrm{X}$ 100 (Sigma Chemical Co.), and homogenized in an ice bath with a motor-driven Ten-Broeck apparatus for $10 \mathrm{~min}$. The homogenized suspension was cleared of particulate debris by centrifugation at 20,000 $g$ for $30 \mathrm{~min}$ and the protein concentration of the supernatant was measured (35). SOD activity was determined by inhibition of ferricytochrome $c$ reduction by acetaldehyde-xanthine oxidase with bovine SOD (Sigma Chemical Co.) as standard (36). Catalase was measured by the decrease in the absorbance of reagent $\mathrm{H}_{2} \mathrm{O}_{2}$ (Fisher Scientific Co.) at $230 \mathrm{~nm}$ in a spectrophotometer (DU-8; Beckman Instruments, Inc.) (28). Bovine catalase (Sigma Chemical Co.) was utilized as a standard. Activity of glutathione peroxidase (GPO) was measured by a modification of method of Hopkins and Tudhope (37); $2.2 \mathrm{mM} t$ butylperoxide (MCB Reagents, E. Merck, Darmstadt, Federal Republic of Germany) was substituted for $\mathrm{H}_{2} \mathrm{O}_{2}$. GPO activity was measured as a decrease in absorbance, $A_{340}$, for NADPH with $\epsilon_{340}$ of $6.22 \mathrm{M}^{-1}$ $\mathrm{cm}^{-1}$. One unit of GPO activity was defined as the amount that causes the oxidation of $1 \mu \mathrm{mol}$ of reduced glutathione per minute at $25^{\circ} \mathrm{C}$.

$\mathrm{H}_{2} \mathrm{O}_{2}$ degradation by live intact eggs was also assessed. Ova $\left(10^{3}\right.$, $10^{4}$, or $2 \times 10^{4}$ ) were suspended in clear HBSS containing 0.5 or 1 $\mathrm{mM} \mathrm{H}_{2} \mathrm{O}_{2}$ and incubated at $37^{\circ} \mathrm{C}$ for $30 \mathrm{~min}$. The parasite eggs were then removed by centrifugation ( $300 \mathrm{~g}$ for $10 \mathrm{~min}$ ) and the absorbance of the $\mathrm{H}_{2} \mathrm{O}_{2}$ solution at $230 \mathrm{~nm}$ was measured (28). The values obtained before and after incubation with ova were compared. In addition, control $\mathrm{H}_{2} \mathrm{O}_{2}$ solutions not containing eggs were also set up and their absorbances at $230 \mathrm{~nm}$ were determined at the beginning and end of the 30-min incubation period.

Statistics. Student's $t$ test was used for assessing the significance of difference between observed means.

\section{Results}

Ultrastructure of PMN-egg interaction. A low-power $(\times 2,600)$ electron micrograph of an egg incubated for 30 min with hilHS or hiNHS and no PMN is shown in Fig. $1 A$. The egg shell consists of dense material with multiple spicules on its outer surface and pores through its thickness. The vitelline membrane and miracidium are located on the internal aspect of the shell. When PMN were added, multiple sites of cell attachment to the eggs were observed with hilHS; rarely did cells adhere to eggs when hiNHS was used. Cell-parasite contact occurred within $30 \mathrm{~min}$. The surfaces of PMN were closely applied to the egg shell and surrounded the multiple spicules (Fig. $1 B$ ). By $4 \mathrm{~h}$ of incubation, complete fracture of the egg shell was observed in some sections (Fig. 2). Eosinophils and neutrophils developed projections that extended through the shell toward the miracidium (Fig. 3). Portions of the egg shell fragments appear to have been ingested by the cells (Fig. 3, inset).

Egg-induced release of $\mathrm{O}_{2}^{-}$and $\mathrm{H}_{2} \mathrm{O}_{2}$ from granulocytes. PMN $\left(2 \times 10^{6}\right)$ mixed with eggs $\left(2 \times 10^{3}\right)$ and $2 \%$ hiNHS released $0.08 \mathrm{nmol} \mathrm{O}_{2}^{-} / \mathrm{min}$ per $2 \times 10^{6}$ cells. There were no significant differences when PMN and eggs were mixed in glass or polypropylene tubes. When fNHS, hilHS, or fIHS were substituted for hiNHS, the rate of SOD-inhibitable ferricytochrome $c(1.2 \mathrm{mg} / \mathrm{ml})$ reduction (measured immediately after addition of eggs to cells) increased respectively by $275(P$ $<0.005), 188(P<0.0025)$, and 550 percent $(P<0.0025$ 


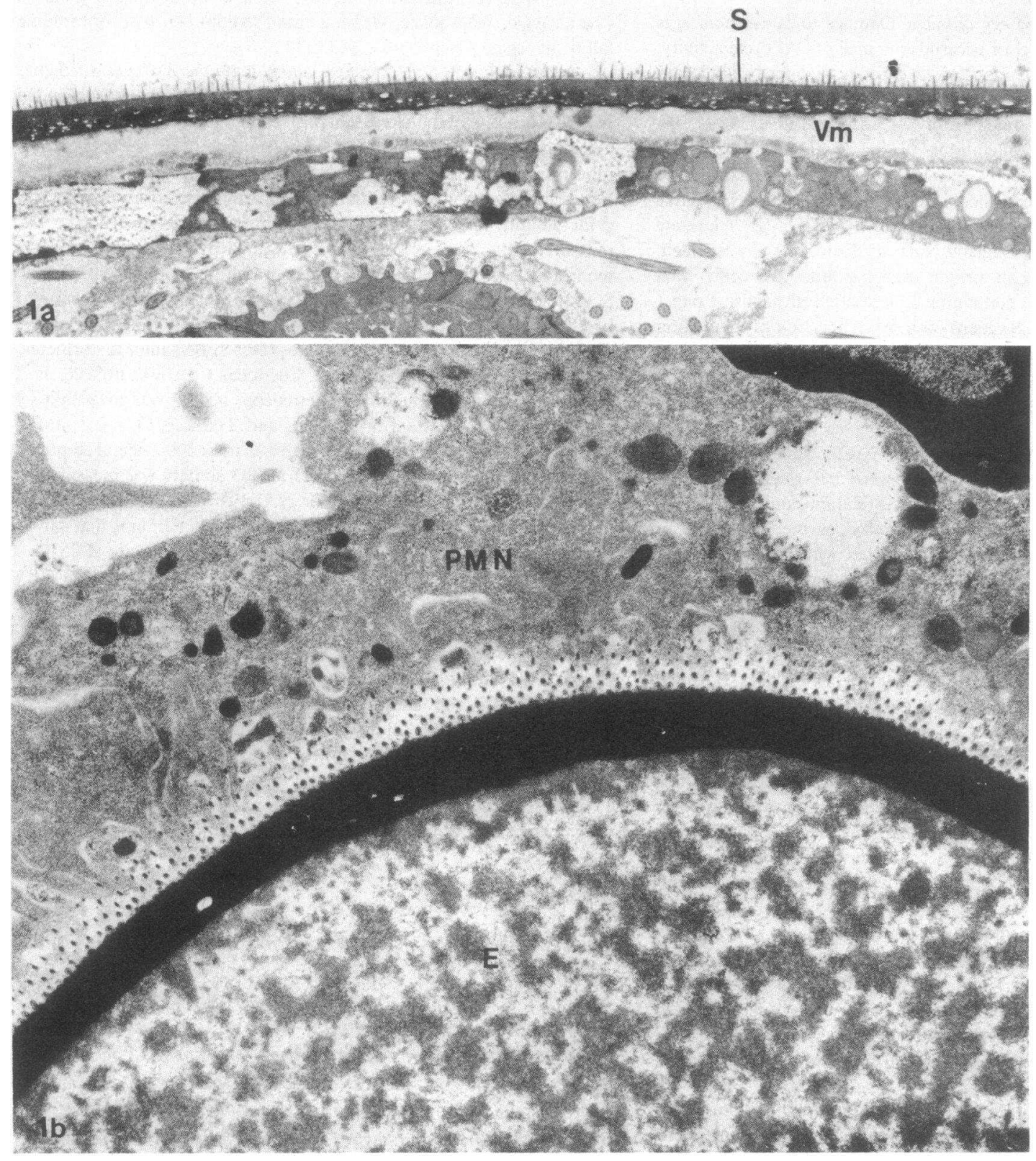

Figure 1. (A) Schistosoma mansoni egg incubated in $2 \%$ heat-inactivated immune serum for $30 \mathrm{~min}$. The egg shell has multiple spicules on its outer surface and covers the underlying vitelline membrane. The multicellular miracidium is situated below the vitelline membrane $(\times 2,600)$. $(B)$ Granulocyte-egg interaction in the presence of

compared with hiNHS) (Table I). Significant quantities of $\mathrm{O}_{2}^{-}$ release by PMN were also observed when cells and eggs were preincubated at $37^{\circ} \mathrm{C}$ for 5,10 , and $30 \mathrm{~min}$ before measurement of cytochrome $c$ reduction (Table I). At all durations of preincubation studied $(5,10$, and $30 \mathrm{~min}), \mathrm{PMN} \mathrm{O}_{2}^{-}$release induced by eggs was greater with fNHS, hilHS, or fIHS than with hiNHS (Table I).

The calculated rate of $\mathrm{O}_{2}$ release was not different when higher concentrations of cytochrome $c$ were used. PMN mixed with eggs and fIHS were calculated to release 0.53 and 0.49 nmol $\mathrm{O}_{2}^{-} / \mathrm{min}$ per $2 \times 10^{6}$ cells at cytochrome $c$ concentrations of 2.4 and $3.6 \mathrm{mg} / \mathrm{ml}$, respectively (results are the mean of
$2 \%$ heat-inactivated immune serum, 30 min of incubation. The granulocyte (PMN) is closely applied to the shell of the egg, which has multiple spicules extending from its surface $(\times 2,600)$. E, egg; S, egg shell; Vm, vitelline membrane.

triplicate samples for two experiments). When the cytochrome $c$ concentration was increased from 1.2 to $2.4 \mathrm{mg} / \mathrm{ml}$ after the 10-min measurement of $\mathrm{O}_{2}^{-}$release, a further increase in the rate of SOD-inhibitable reduction of cytochrome $c$ was also not detected. Addition of $0.1 \mu \mathrm{g}$ of PMA $/ \mathrm{ml}$ to cells and eggs incubated with fIHS for $10 \mathrm{~min}$ increased $\mathrm{O}_{2}^{-}$release from $0.52 \pm 0.10$ to $4.63 \pm 0.58 \mathrm{nmol} / \mathrm{min}$ (mean $\pm \mathrm{SE}$ of four experiments). A similar number of PMN not exposed to eggs released $5.23 \pm 0.49 \mathrm{nmol} \mathrm{O}_{2}^{-} / \mathrm{min}$ per $2 \times 10^{6}$ cells after addition of $0.1 \mu \mathrm{g}$ of PMA $/ \mathrm{ml}$.

When PMN adherent to eggs were separated from nonadherent $\mathrm{PMN}$ and $\mathrm{O}_{2}^{-}$release was measured, the PMN adherent 


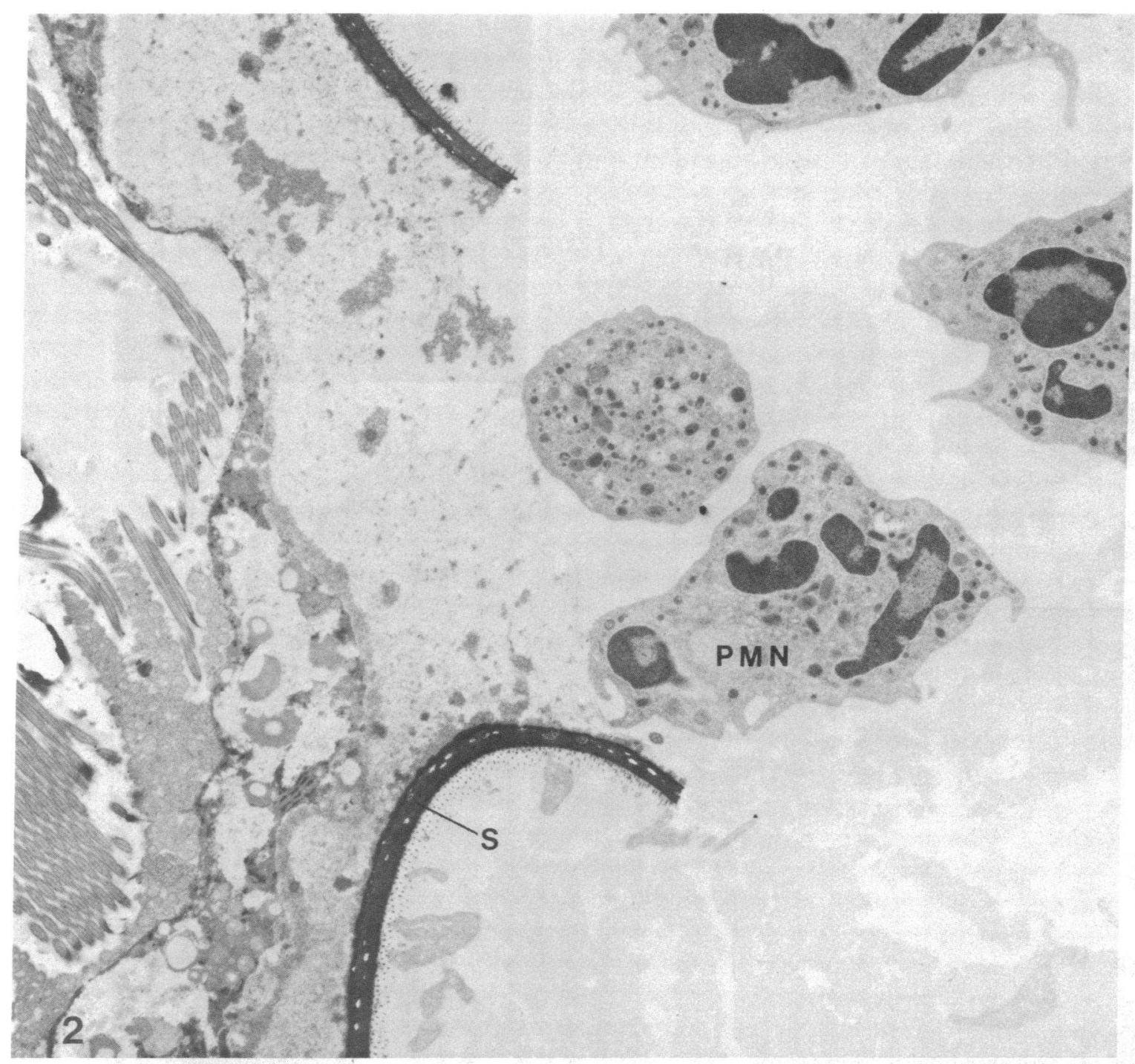

Figure 2. Granulocyte-egg interaction in the presence of $2 \%$ heat-inactivated immune serum, $4 \mathrm{~h}$ of incubation. The egg shell is fractured and granulocytes $(P M N)$ are attached to the underlying structures $(\times 2,600)$.

to eggs released a total of $0.84,2.84$, and $3.44 \mathrm{nmol} \mathrm{O}_{2}^{-}$per 2 $\times 10^{6}$ cells after 10,30 , and $60 \mathrm{~min}$, respectively. (These values are given as the total amount of detectable $\mathrm{O}_{2}^{-}$accumulated over the entire time interval rather than as nanomoles released/ minute because the rates were not constant and lower than that observed when PMN and egg were incubated together as described for Table I). At corresponding time intervals, nonadherent PMN released a total of $<0.06,0.07$, and $0.08 \mathrm{nmol}$ $\mathrm{O}_{2}^{-}$. There were $9.6 \times 10^{6}$ cells in the nonadherent population; the remaining cells $\left(0.4 \times 10^{6}\right)$ were assumed to be adherent to the parasite ova. When PMA was added to adherent PMN, $\mathrm{O}_{2}^{-}$release increased to $6.30 \mathrm{nmol} / 10 \mathrm{~min}$.

Supernatants $(10,50$, or $100 \mu \mathrm{l})$ of eggs incubated with $2 \%$ hiNHS, fNHS, or hilHS for $18 \mathrm{~h}$ did not induce PMN $\mathrm{O}_{2}^{-}$ production $\left(<0.06 \mathrm{nmol} / \mathrm{min}\right.$ per $\left.2 \times 10^{6}\right)$. Furthermore, reduction of ferricytochrome $c$ by eggs incubated without granulocytes did not occur. Inclusion of SOD $(10 \mu \mathrm{g} / \mathrm{ml})$ in any of the cell-egg-sera mixtures resulted in $>90 \%$ inhibition of ferricytochrome $c$ reduction.

Egg-induced release of $\mathrm{H}_{2} \mathrm{O}_{2}$ by PMN was also observed.
The rate of $\mathrm{H}_{2} \mathrm{O}_{2}$ release for PMN $\left(2 \times 10^{6}\right)$ preincubated for 10 min with eggs $\left(10^{3}\right)$ and $2 \%$ hiNHS or $2 \%$ hilHS was $0.03 \pm 0.01 \mathrm{nmol} / \mathrm{min}$ per $2 \times 10^{6}$ cells (mean $\pm \mathrm{SE}$ of four experiments). When fNHS or fIHS were utilized, $\mathrm{H}_{2} \mathrm{O}_{2}$ accumulation increased, respectively, to $0.14 \pm 0.03$ and $0.15 \pm 0.01$ $\mathrm{nmol} / \mathrm{min}(P<0.05$ and $<0.005) . \mathrm{H}_{2} \mathrm{O}_{2}$ release was not detectable in the presence of catalase $(1,250 \mathrm{U} / \mathrm{ml})$.

$P M N$-mediated reduction in predicted egg TCA cycle activity and hatching: effects of heparin, exogenous scavenger enzymes, and peroxidase inhibitors. In preliminary studies, ${ }^{14} \mathrm{CO}_{2}$ generated in cell-ova mixtures was found to be primarily related to egg and not PMN metabolism of labeled acetate. PMN (5 $\left.\times 10^{6}\right)$ incubated alone or with dead (freeze-thawed) eggs and $2 \%$ fIHS generated $3,000-10,000 \mathrm{cpm}{ }^{14} \mathrm{CO}_{2}$ (range of five experiments) compared with $15,000-55,000 \mathrm{cpm}$ for mixtures containing live eggs (range of 12 experiments). Generation of ${ }^{14} \mathrm{CO}_{2}$ from $\left[2-{ }^{14} \mathrm{C}\right]$ acetate by eggs was associated with metabolism of acetate by the miracidium and not the egg shell. The values for ${ }^{14} \mathrm{CO}_{2}$ accumulation by "intact" eggs, freshly released miracidia, and "hatched" eggs (a mixture that contained $20 \%$ 


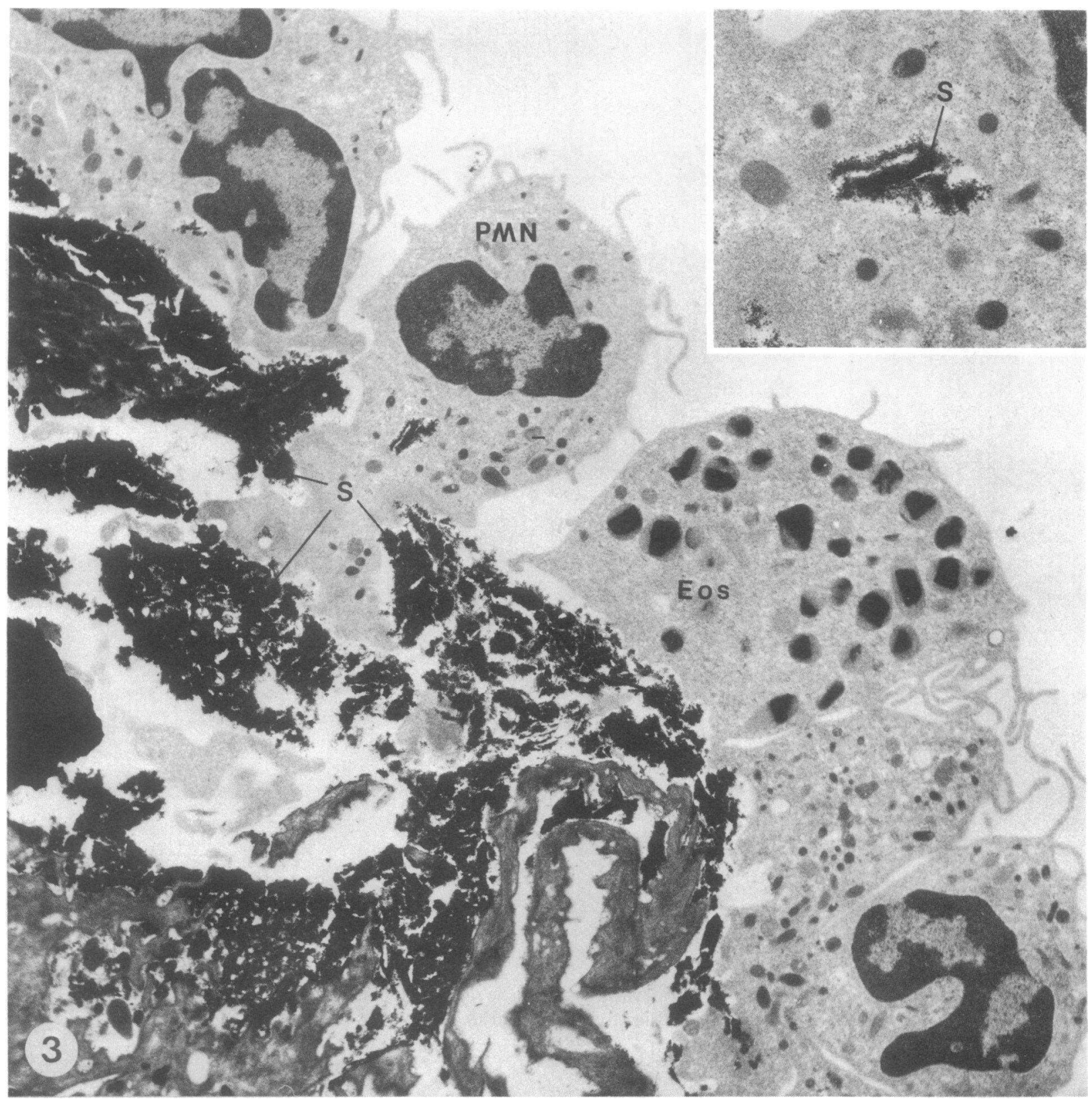

Figure 3. A granulocyte (PMN) and eosinophil are attached to an egg whose shell has been disrupted in multiple areas. PMN has a cellular projection that extends inward toward the miracidium $(\times 2,600)$. (Inset) Fragment of egg shell that has been ingested by a PMN (× 8,300). Eos, eosinophil; S, egg shell.

intact eggs as well) were, respectively, 10,268, 14,442, and $1,512 \mathrm{cpm}$ per $5 \times 10^{3}$ parasites (mean of two experiments with triplicate determinations in each).

Incubation of eggs $\left(5 \times 10^{3}\right)$ with PMN $\left(5 \times 10^{6}\right)$ and $2 \%$ hilHS led to $28.3 \pm 0.9 \%$ reduction in predicted ${ }^{14} \mathrm{CO}_{2}$ generation from $\left[2-{ }^{14} \mathrm{C}\right]$ acetate and $35.2 \pm 2.8 \%$ decrease in hatching. Heparin $(500 \mathrm{U} / \mathrm{ml})$, a substance that prevents binding of eosinophil major basic protein to helminths (38), did not decrease these PMN-induced alterations in egg function (Table II). In contrast, inclusion of $10 \mu \mathrm{g}$ of $\mathrm{SOD} / \mathrm{ml}$ in the PMN-egg mixtures prevented the effect of PMN on egg TCA cycle activity and markedly diminished granulocyte-mediated reduction in hatching (35.2\% decrease in hatching induced by PMN without SOD vs. $12.5 \%$ in the presence of SOD, $P<0.0005$ ) (Table
II). Catalase $(5,000 \mathrm{U} / \mathrm{ml})$ did not alter PMN-induced changes in egg acetate metabolism and hatching; catalase plus SOD had an effect similar to SOD alone (Table II).

To assess the possibility that myeloperoxidase or eosinophil peroxidase released from PMN catabolized $\mathrm{H}_{2} \mathrm{O}_{2}$ and thereby prevented this molecule from damaging the underlying miracidium, the effects of peroxidase inhibitors on PMN-induced suppression of egg acetate metabolism were measured. In two experiments, PMN induced 35 and $31 \%$ reduction in the amount of ${ }^{14} \mathrm{CO}_{2}$ generated from $\left[2-{ }^{14} \mathrm{C}\right]$ acetate compared with the quantity predicted from PMN and eggs incubated separately (Table III). In experiment 1 , inclusion of $1 \mathrm{mM}$ azide, cyanide, or methimazole in the cell-parasite mixtures led to $44-48 \%$ suppression of egg acetate metabolism compared with $35 \%$ in 
Table I. PMN $\mathrm{O}_{2}^{-}$Release Induced by S. mansoni Eggs: Relation of Duration of Incubation to Level of $\mathrm{O}_{2}^{-}$Production*

\begin{tabular}{|c|c|c|c|c|}
\hline \multirow{2}{*}{$\begin{array}{l}\text { Time of preincubation before } \\
\text { measurement of } \mathrm{O}_{2}^{-} \text {release }\end{array}$} & \multicolumn{4}{|c|}{ Rate of $\mathrm{PMN} \mathrm{O}_{2}^{-}$release according to source of serum added $\ddagger$} \\
\hline & hiNHS & fNHS & hilHS & fIHS \\
\hline 0 & $0.08 \pm 0.01$ & $0.30 \pm 0.01$ & $0.23 \pm 0.02$ & $0.52 \pm 0.10$ \\
\hline 5 & $0.06 \pm 0.02$ & $0.32 \pm 0.04$ & $0.22 \pm 0.03$ & $0.43 \pm 0.06$ \\
\hline 30 & $0.07 \pm 0.01$ & $0.21 \pm 0.04$ & $0.20 \pm 0.02$ & $0.21 \pm 0.02$ \\
\hline
\end{tabular}

* PMN $\left(2 \times 10^{6}\right)$ and $S$. mansoni eggs $\left(2 \times 10^{3}\right)$ were mixed in the presence of $2 \%$ vol/vol sera and preincubated at $37^{\circ} \mathrm{C}$ for the times indicated before $\mathrm{O}_{2}^{-}$release was measured for a period of $10 \mathrm{~min}(23)$. $¥$ Results represent the mean $\pm \mathrm{SE}$ of experiments with PMN of four to six donors.

controls without peroxidase inhibitors. Similar enhancement of PMN-mediated toxicity was observed in experiment 2 (Table III).

Changes in egg activities induced by $\mathrm{H}_{2} \mathrm{O}_{2}$ and oxidants generated by acetaldehyde-xanthine oxidase. Exposure of eggs to $10 \mu \mathrm{M}, 100 \mu \mathrm{M}$, and $1 \mathrm{mM} \mathrm{H}_{2} \mathrm{O}_{2}$ reduced egg generation of ${ }^{14} \mathrm{CO}_{2}$ from $\left[2-{ }^{14} \mathrm{C}\right]$ acetate by $24.8-81.2 \%$ compared with control ova (Table IV); hatching was not inhibited by 10 or $100 \mu \mathrm{M} \mathrm{H}_{2} \mathrm{O}_{2}$ but was decreased by $70.5 \pm 6.1 \%$ in the presence of $1 \mathrm{mM} \mathrm{H}_{2} \mathrm{O}_{2}(P<0.0025$ vs. control, Table IV). Acetaldehyde $(2 \mathrm{mM})$ or xanthine oxidase $(10 \mathrm{mU} / \mathrm{ml})$ had no effect on acetate metabolism or hatching when these substances were individually added to egg suspensions. In contrast, the combination of acetaldehyde and xanthine oxidase reduced apparent TCA cycle activity by $62.0 \pm 9.0 \%$ at $18 \mathrm{~h}$ incubation $(P$ $<0.0025$, Table IV). Hatching was also decreased $38.7 \%$ by exposure to acetaldehyde-xanthine oxidase for $18 \mathrm{~h}$ (Table III). After 2 and $6 \mathrm{~h}$ of exposure to acetaldehyde-xanthine, hatching was decreased by 20 and $37 \%$, respectively, compared with controls. There were no further decreases in hatching when eggs were incubated for 24 or $48 \mathrm{~h}$ (40 and 33\% inhibition, respectively) (results are the mean of duplicate experiments at each time point). Acetaldehyde and xanthine oxidase generated $\mathrm{O}_{2}^{-}$at a maximal rate of $1.18 \mathrm{nmol} / \mathrm{min}$ within the first $3 \mathrm{~min}$ of mixing. After $10 \mathrm{~min}$, the rate decreased to $0.18 \mathrm{nmol} / \mathrm{min}$. Production of $\mathrm{O}_{2}^{-}$was not detectable $2 \mathrm{~h}$ after acetaldehyde and xanthine oxidase were mixed. When $10 \mu \mathrm{g}$ of SOD $/ \mathrm{ml}$ or $5,000 \mathrm{U}$ of catalase/ml were added to acetaldehyde-xanthine oxidase, the deleterious effects of this oxidant-generating system on egg activities were decreased. The percentage reductions in TCA cycle activity and hatching induced by acetaldehydexanthine oxidase in the presence of SOD were 26 and $<1 \%$; catalase alone or when added with SOD completely abrogated the effects of acetaldehyde-xanthine oxidase $(0 \%$ reduction in TCA cycle activity and hatching) (Table IV). SOD and catalase did not prevent egg toxicity of acetaldehyde-xanthine oxidase if the scavenger enzymes were boiled for $30 \mathrm{~min}$ before addition to the egg suspensions (data not shown). Mannitol, benzoate, or histidine did not reverse the effects of acetaldehydexanthine oxidase on egg TCA cycle activity and hatching (Table IV) and did not affect these egg functions in the absence of the oxidant generating system (data not shown). Diazobicyclooctane (1-10 mM) had a direct toxic effect on egg TCA cycle activity $\left(74.0 \%\right.$ reduction in ${ }^{14} \mathrm{CO}_{2}$ generation from [2-

Table II. Effects of Heparin and Antioxidant Scavenger Enzymes on PMN-induced Alterations in S. mansoni Egg Acetate Metabolism and Hatching

\begin{tabular}{|c|c|c|c|c|}
\hline $\begin{array}{l}\text { Inhibitors added to } \\
\text { PMN-egg mixtures }\end{array}$ & $\begin{array}{l}\text { Percent reduction } \\
\text { in egg acetate } \\
\text { metabolism } \\
\text { induced by } \mathrm{PMN}^{*}\end{array}$ & $P$ value & $\begin{array}{l}\text { Percent reduction in } \\
\text { hatching induced by } \\
\text { PMN } \ddagger\end{array}$ & $P$ value \\
\hline No addition (control) & $28.3 \pm 0.9$ & $\begin{array}{l}<0.0025 \text { vs. PMN and eggs } \\
\text { incubated separately }\end{array}$ & $35.2 \pm 2.8$ & $\begin{array}{l}<0.0025 \text { vs. eggs incubated } \\
\text { without PMN }\end{array}$ \\
\hline Heparin $(500 \mathrm{U} / \mathrm{ml})$ & $43.3 \pm 7.3$ & $>0.10$ vs. control & $30.0 \pm 5.3$ & $>0.10$ vs. control \\
\hline $\operatorname{SOD}(10 \mu \mathrm{g} / \mathrm{ml})$ & $3.0 \pm 2.1$ & $<0.0005$ vs. control & $12.5 \pm 1.8$ & $<0.0005$ vs. control \\
\hline Catalase $(5,000 \mathrm{U} / \mathrm{ml})$ & $31.7 \pm 2.0$ & $>0.10$ vs. control & $29.3 \pm 4.5$ & $>0.10$ vs. control \\
\hline $\begin{array}{l}\text { Catalase }(5,000 \mathrm{U} / \mathrm{ml}) \\
\quad+\operatorname{SOD}(10 \mu \mathrm{g} / \mathrm{ml})\end{array}$ & $8.3 \pm 4.3$ & $<0.0025$ vs. control & $7.0 \pm 2.3$ & $<0.0005$ vs. control \\
\hline
\end{tabular}

${ }^{*} \mathrm{PMN}\left(5 \times 10^{6}\right)$ and eggs $\left(5 \times 10^{3}\right)$ were incubated together with $2 \%$ hilHS and the percentage of reduction in egg ${ }^{14} \mathrm{CO}_{2}$ generation induced by PMN was calculated by comparison with the sum predicted from PMN and eggs incubated separately with $2 \%$ hilHS (17, 27). Results represent the mean \pm SE of five experiments. $\ddagger$ PMN $\left(5 \times 10^{6}\right)$ and eggs $\left(5 \times 10^{3}\right)$ were incubated together with $2 \%$ hilHS and the hatching rate (miracidia released per 100 eggs) was determined after $24 \mathrm{~h}$. This value was compared with the hatching rate of control eggs incubated in $2 \%$ hilHS without PMN. The percent reduction induced by PMN was calculated from these values (17, 27). Results represent mean \pm SE of three experiments. 
Table III. Effect of Peroxidase Inhibitors on PMN-induced Suppression in Acetate Metabolism of S. mansoni Eggs*

\begin{tabular}{|c|c|c|c|}
\hline \multirow[b]{2}{*}{$\begin{array}{l}\text { Peroxidase } \\
\text { inhibitor added }\end{array}$} & \multirow[b]{2}{*}{$\begin{array}{l}\text { Contents of } \\
\text { culture vessels }\end{array}$} & \multicolumn{2}{|c|}{$\begin{array}{l}\text { Amount of }{ }^{14} \mathrm{CO}_{2} \\
\text { generated from } \\
{\left[2-{ }^{14} \mathrm{C}\right] \text { acetate }}\end{array}$} \\
\hline & & $\begin{array}{l}\text { Experiment } \\
1\end{array}$ & $\begin{array}{l}\text { Experiment } \\
2\end{array}$ \\
\hline & & $c p m$ & $c p m$ \\
\hline \multirow{4}{*}{$\begin{array}{l}\text { None } \\
\text { (control) }\end{array}$} & PMN alone & $10,738 \ddagger$ & $17,614 \ddagger$ \\
\hline & Eggs alone & 11,607 & 16,500 \\
\hline & PMN + eggs & 14,493 & 23,600 \\
\hline & $\begin{array}{l}\text { (\% reduction in cpm } \\
\text { induced by } \mathrm{PMN \S})\end{array}$ & $(35 \%)$ & $(31 \%)$ \\
\hline \multirow{4}{*}{$\begin{array}{l}\text { Azide } \\
\qquad(1 \mathrm{mM})\end{array}$} & PMN alone & 6,514 & 15,832 \\
\hline & Eggs alone & 13,463 & 22,005 \\
\hline & PMN + eggs & 11,288 & 15,820 \\
\hline & $\begin{array}{l}\text { (\% reduction in cpm } \\
\text { induced by PMN§) }\end{array}$ & $(44 \%)$ & $(58 \%)$ \\
\hline \multirow{4}{*}{$\begin{array}{l}\text { Cyanide } \\
\qquad(1 \mathrm{mM})\end{array}$} & PMN alone & 8,024 & 13,305 \\
\hline & Eggs alone & 8,889 & 13,613 \\
\hline & PMN + eggs & 8,778 & 13,710 \\
\hline & $\begin{array}{l}\text { (\% reduction in cpm } \\
\text { induced by PMN§) }\end{array}$ & $(48 \%)$ & $(49 \%)$ \\
\hline \multirow{4}{*}{$\begin{array}{l}\text { Methimazole } \\
\text { (1 mM) }\end{array}$} & PMN alone & 9,945 & 19,801 \\
\hline & Eggs alone & 13,972 & 18,005 \\
\hline & PMN + eggs & 13,062 & 17,400 \\
\hline & $\begin{array}{l}\text { (\% reduction in cpm } \\
\text { induced by } \mathrm{PMN} \S \text { ) }\end{array}$ & $(45 \%)$ & $(54 \%)$ \\
\hline
\end{tabular}

* PMN $\left(2 \times 10^{6}\right)$ and eggs $\left(2 \times 10^{3}\right)$ were incubated together or separately with $2 \%$ hilHS and the amount of ${ }^{14} \mathrm{CO}_{2}$ generated from [2${ }^{14} \mathrm{C}$ lacetate after an 18 -h period measured, as described in Methods $(17,26,27)$.

$¥$ Mean of duplicate determinations for all values in this column. $\S$ This value was calculated by the formula: [cpm (PMN alone)

$+\mathrm{cpm}$ (eggs alone) $-\mathrm{cpm}(\mathrm{PMN}+\mathrm{eggs})] /[\mathrm{cpm}$ (PMN alone)

$+\mathrm{cpm}$ (eggs alone) $] \times 100$.

${ }^{14} \mathrm{C}$ ]acetate) and hatching (60\% reduction) and was thus not utilized in further studies.

Effect of cell-free oxidants on egg-induced granuloma formation. The area of egg-induced granulomas in mice injected with $S$. mansoni ova was $27,671 \pm 2,280 \mu \mathrm{m}^{2}$ (mean \pm standard error of the mean granulomas from six mice each injected with 2,000 eggs). Preincubation of eggs for $24 \mathrm{~h}$ with $1 \mathrm{mM}$ $\mathrm{H}_{2} \mathrm{O}_{2}$ resulted in a mean granuloma area of $7,236 \pm 610 \mu \mathrm{m}^{2}$ ( $P<0.001$ compared with controls). Exposure of eggs to 100 $\mu \mathrm{M}$ or $10 \mu \mathrm{M} \mathrm{H}_{2} \mathrm{O}_{2}$ had no significant effect on granuloma area. The mean granuloma area induced by eggs preincubated with $2 \mathrm{mM}$ acetaldehyde and $10 \mathrm{mU}$ xanthine oxidase/ml was $24,600 \pm 2,780 \mu \mathrm{m}^{2}$ (results of injection of 2,000 eggs each into six mice; $P>0.10$ compared with controls). Inclusion of 10 $\mu \mathrm{g}$ of $\mathrm{SOD} / \mathrm{ml}$ with this oxidant-generating system and eggs resulted in a granuloma area of $27,500 \pm 6,170 \mu \mathrm{m}^{2}$ (mean \pm SE of mean granulomas from six mice). This value was not significantly different $(P>0.05)$ from that obtained in mice injected with control egg preparations or ova exposed to acetaldehyde-xanthine oxidase.
Catalase, SOD, and GPO activities of eggs. Catalase was undetectable in egg extracts $(<0.025 \mathrm{U} / \mathrm{mg}$ of protein, results of experiments with five different egg preparations). Intact eggs also did not degrade $\mathrm{H}_{2} \mathrm{O}_{2}$. The $A_{230}$ of 0.5 and $1.0 \mathrm{mM}$ solutions of $\mathrm{H}_{2} \mathrm{O}_{2}$ were 0.0412 and 0.0830 , respectively, before and after incubation for $30 \mathrm{~min}$ with $10^{3}, 10^{4}$, or $2 \times 10^{4}$ freshly isolated live $S$. mansoni eggs. Control solutions of 0.5 and $1.0 \mathrm{mM} \mathrm{H} \mathrm{H}_{2} \mathrm{O}_{2}$ not exposed to parasite ova had $A_{230}$ of 0.0403 and 0.0805 , respectively. SOD at a mean level of $0.74 \pm 0.01 \mathrm{U} / \mathrm{mg}$ of protein was present in soluble ova extracts (four separate experiments). Superoxide production as measured by ferricytochrome $c$ reduction was not detectable when intact eggs $\left(1-5 \times 10^{3}\right)$ or parasite extracts (1-100 $\mu \mathrm{g}$ of protein) were added to 1 or $10 \mathrm{mM}$ acetaldehyde (in the absence of exogenous xanthine oxidase). GPO activity was detected at a level of $8.6 \mathrm{U} / \mathrm{mg}$ of parasite protein (mean value of two experiments).

\section{Discussion}

The microbicidal function of PMN primarily occurs in confined subcellular spaces where toxic mediators are highly concentrated around the invading microorganism. In contrast, killing of nonphagocytosable helminths such as $S$. mansoni schistosomula is initiated at extracellular sites of intimate contact between the PMN plasma membrane and parasite surface $(39,40)$. PMN-mediated host defense against schistosome ova represents, however, an unusual and little-studied model of the effector function of leukocytes. The metabolically active and antigenproducing miracidium is enclosed within a hard nonliving shell and does not migrate through or directly interact with the surrounding host environment. Despite these qualities, schistosome eggs are actively eliminated by the host in a process that is at least in part effected by eosinophils $(7,8)$. In the present in vitro study, electron microscopic analysis of human PMN interaction with eggs showed that both neutrophils and eosinophils attach to the parasite shell, interdigitate closely with the protruding microspicules, and eventually cause its fracture. Cellular projections are subsequently extended inward toward the miracidium within the shell. Damage to ova thus may occur in a two-step sequence: the first involves intimate contact between the PMN and egg shell leading to its physical interruption and the second is associated with approximation of PMN pseudopodia to the miracidium. Ultrastructural analysis of egg granulomas in the livers of mice with $S$. mansoni infection indicate that a similar process may occur in vivo $(12,41)$. In these studies, partially disintegrated eggs and shell remnants were observed in the phagosomes of adjacent cells.

PMN interaction with eggs and serum containing antiparasite antibodies or complement resulted in metabolic activation of these cells with release of $\mathrm{O}_{2}^{-}$and $\mathrm{H}_{2} \mathrm{O}_{2}$. Oxidants were primarily produced by cells attached to ova, as adherent PMN generated $\sim 20$ times more $\mathrm{O}_{2}^{-}$than $\mathrm{PMN}$ not associated with eggs. In addition, supernatants of eggs preincubated with fNHS or hilHS failed to stimulate PMN oxidant production. These data suggest that activation of the respiratory burst by $S$. mansoni ova is dependent on direct contact between PMN and ligand-coated parasites. Fluid-phase immune complexes or activated complement components that may be generated in mixtures of eggs and sera or present in the sera of infected subjects do not appear to be sufficient to stimulate PMN oxidant production $(42,43)$. 
Table IV. Effects of Oxidants Generated in Cell-free Systems on Apparent TCA Cycle Activity and Hatching of S. mansoni Eggs

\begin{tabular}{|c|c|c|c|c|}
\hline $\begin{array}{l}\text { Oxidants/scavengers added } \\
\text { to } 5 \times 10^{3} \text { eggs }\end{array}$ & $\begin{array}{l}\text { Percent reduction of } \\
{ }^{14} \mathrm{CO}_{2} \text { generation } \\
\text { from }\left[2{ }^{-1} \text { Clacetate* }\right.\end{array}$ & $P$ value & $\begin{array}{l}\text { Percent } \\
\text { reduction in } \\
\text { hatching* }\end{array}$ & $P$ value \\
\hline None (control) & 0 & - & 0 & - \\
\hline $\mathrm{H}_{2} \mathrm{O}_{2}(10 \mu \mathrm{M}) \ddagger$ & $24.8 \pm 4.5$ & $<0.005$ vs. control & $8.5 \pm 8.5 \ddagger$ & $>0.10$ vs. control \\
\hline $\mathrm{H}_{2} \mathrm{O}_{2}(100 \mu \mathrm{M})$ & $28.0 \pm 13.0$ & $<0.09$ vs. control & $12.0 \pm 8.5 \ddagger$ & $>0.10$ vs. control \\
\hline $\mathrm{H}_{2} \mathrm{O}_{2}(1 \mathrm{mM})$ & $81.2 \pm 4.3$ & $<0.0005$ vs. control & $70.5 \pm 6.1 \ddagger$ & $<0.0025$ vs. control \\
\hline $\mathrm{AC}(2 \mathrm{mM}) \ddagger$ & $2.1 \pm 1.8$ & - & $13.7 \pm 1.7 \ddagger$ & - \\
\hline $\mathrm{XO}(10 \mathrm{mU} / \mathrm{ml})$ & $3.5 \pm 1.7$ & - & $0 \ddagger$ & - \\
\hline AC-XO & $62.0 \pm 9.0$ & $\begin{array}{l}<0.0025 \text { vs. } \mathrm{AC} \text { or } \mathrm{XO} \\
\text { alone }\end{array}$ & $38.7 \pm 7.3 \ddagger$ & $\begin{array}{l}<0.05 \text { vs. } \mathrm{AC} \text { or } \mathrm{XO} \\
\text { alone }\end{array}$ \\
\hline $\mathrm{AC}-\mathrm{XO}+\mathrm{SOD}(10 \mu \mathrm{g} / \mathrm{ml})$ & $26.5 \pm 4.2$ & $<0.005$ vs. AC-XO & $0.7 \pm 0.7 \ddagger$ & $<0.0025$ vs. $\mathrm{AC}-\mathrm{XO}$ \\
\hline $\mathrm{AC}-\mathrm{XO}+$ catalase $(5,000 \mathrm{U} / \mathrm{ml})$ & 0 & - & 0 & - \\
\hline AC-XO + mannitol $(10 \mathrm{mM}) \S$ & 60.0 & - & $40.2 \S$ & - \\
\hline AC-XO + benzoate $(10 \mathrm{mM})$ & 58.7 & - & $39.8 \S$ & - \\
\hline AC-XO + histidine $(10 \mathrm{mM})$ & 64.5 & - & $34.8 \S$ & - \\
\hline
\end{tabular}

Abbreviations used in this table: AC, acetaldehyde; SOD, superoxide dismutase; XO, xanthine oxidase. ${ }^{*} 5 \times 10^{3}$ eggs were incubated in $2 \%$ $\mathrm{vol} /$ vol hiNHS for $18 \mathrm{~h}$ and conversion of $\left[2-{ }^{14} \mathrm{C}\right]$ acetate to ${ }^{14} \mathrm{CO}_{2}$ and hatching measured as described in Methods $(17,26,27)$. $¥$ Results represent mean $\pm \mathrm{SE}$ of three separate experiments for studies with $\mathrm{H}_{2} \mathrm{O}_{2}$ and with acetaldehyde-xanthine oxidase. $\S$ Results represent mean of two experiments with mannitol, benzoate, or histidine.

Further evaluation of PMN respiratory burst activity induced by eggs showed that $\mathrm{O}_{2}^{-}$release persisted for at least 30 min after cells and parasites were mixed. Addition of the soluble activator PMA led to the generation of greater amounts of $\mathrm{O}_{2}^{-}$. This pattern of oxidant production, characterized by the release of submaximal amounts of reduced oxygen products over a relatively long period of time, has also been noted for PMN-schistosomula interaction and may be peculiar to granulocyte interaction with multicellular helminths $(3,4)$. In this situation, multiple PMN attach to the surface of the nonphagocytosable helminth and attack discrete and small areas of the organism's surface, unlike bacteria and protozoa, which are sequestered rapidly into phagocytic vacuoles. In the case of the $S$. mansoni ovum, the metabolically active miracidium lies beneath the egg shell and is physically separated from the attached PMN. Quantities of effector molecules sufficient to damage the miracidium might only be achieved if the PMN generates and releases these molecules at a moderate rate over a long period of time. If large amounts of oxygen radicals or other microbicidal substances were rapidly produced, burst activity might be terminated before the cell damages its helminthic target (44). Furthermore, the viability of neighboring adherent PMN or other host tissues might be affected by exposure to high oxidant fluxes (45).

To assess the importance of oxygen-derived molecules as effectors of leukocyte-mediated host defense against ova, the ability of $\mathrm{O}_{2}^{-}$and $\mathrm{H}_{2} \mathrm{O}_{2}$ degradative enzymes to inhibit egg damage were examined. SOD, an enzyme that degrades $\mathrm{O}_{2}^{-}$, inhibited the deleterious effects of PMN on egg TCA metabolism and hatching. In contrast, catalase, an enzyme that degrades $\mathrm{H}_{2} \mathrm{O}_{2}$, did not affect these $\mathrm{PMN}$-induced alterations in egg function. This difference in the abilities of SOD and catalase to inhibit leukocyte-mediated parasite damage may be related to the unusual anatomic relationship that pertains to PMN-egg interaction. When PMN attach to the ligand- coated egg shell, the cells presumably release myeloperoxidase/ eosinophil peroxidase as well as generate $\mathrm{O}_{2}^{-}$and $\mathrm{H}_{2} \mathrm{O}_{2}$. Whereas low molecular weight-reduced oxygen products may pass readily through the porous egg shell, large molecules such as myeloperoxidase or eosinophil peroxidase are unlikely to reach the miracidium at a rapid rate. These peroxidases may catabolize PMN-derived $\mathrm{H}_{2} \mathrm{O}_{2}$ at the egg shell or in other areas sufficiently far from the target miracidium to prevent peroxide toxicity. Superoxide, on the other hand, may escape degradation and proceed past the egg shell to reach the metabolically active miracidium, where it or more toxic oxygen radicals may damage this portion of the ovum. The observation that the rate of detectable extracellular accumulation of $\mathrm{H}_{2} \mathrm{O}_{2}$ is relatively lower than that $\mathrm{O}_{2}^{-}\left(0.15 \mathrm{vs} .0 .52 \mathrm{nmol} / \mathrm{min}\right.$ per $2 \times 10^{6}$ PMN in the presence of fIHS) is consistent with peroxidasecatalyzed degradation of $\mathrm{H}_{2} \mathrm{O}_{2}$. It was also noted that azide, cyanide, and methimazole increased the level of PMN-mediated damage to egg TCA cycle activity by 26 to $87 \%$, suggesting that cellular-derived $\mathrm{H}_{2} \mathrm{O}_{2}$ in the absence of these peroxidase inhibitors is catabolized before reaching the target miracidium.

The capacity of various oxygen products to damage schistosome ova was confirmed in studies employing cell-free oxidant-generating systems. Egg TCA cycle activity was significantly reduced by $\geqq 10 \mu \mathrm{M} \mathrm{H} \mathrm{H}_{2} \mathrm{O}_{2}$. Acetaldehyde-xanthine oxidase, which generates $\mathrm{H}_{2} \mathrm{O}_{2}, \mathrm{O}_{2}^{-}$, and $\mathrm{OH}^{\circ}$, also decreased the level of activity of this metabolic pathway in eggs (32). Addition of SOD, which degrades $\mathrm{O}_{2}^{-}$, partially inhibited the toxicity of this oxidant-generating system whereas catalase, which degrades $\mathrm{H}_{2} \mathrm{O}_{2}$, completely prevented egg damage. These results are consistent with a major role for $\mathrm{H}_{2} \mathrm{O}_{2}$ and/or derivatives of this molecule as mediators of egg damage. In the case of PMN, where large amounts of cellular-generated $\mathrm{H}_{2} \mathrm{O}_{2}$ may be degraded before reaching the miracidium, $\mathrm{O}_{2}^{-}$ released from PMN may be converted to oxygen radicals with greater microbicidal activity via intraparasitic dismutation 
and/or iron-dependent Haber-Weiss reactions (46-49). The failure of $\mathrm{OH}^{\cdot}$ and ${ }^{1} \mathrm{O}_{2}$ scavengers such as mannitol, benzoate, and histidine to protect eggs against damage in cell-free oxidantgenerating systems does not exclude a role for these reduced oxygen products, as the accessibility of the scavengers to sites within the ovum is not known.

Egg TCA cycle activity, hatching, and ability to induce granulomas in vivo were used to assess parasite damage in the present study. Conversion of $\left[2-{ }^{14} \mathrm{C}\right]$ acetate to ${ }^{14} \mathrm{CO}_{2}$ was noted to be more susceptible to inhibition by artificially generated oxygen products than the latter two activities of the egg. These differences in the susceptibility of various eggs functions to the deleterious effects of reduced oxygen products may be related to several factors. First, slight reduction in the level of egg acetate metabolism may be more readily detected and quantifiable than changes in hatching or granuloma formation. Second, TCA cycle activity represents a well-defined biochemical pathway that may be altered by damage to one or a few key enzymes. Hatching, on the other hand, is the culmination of multiple biologic processes. Severe damage to several of these processes may be needed to be manifest as a decrease in the release of miracidia. Finally, granuloma formation is the result of a complex series of host cellular reactions to antigens released from eggs. Reduction in size of these pathologic lesions may be dependent on nonoxidative mechanisms of egg injury that are not present in cell-free oxidant-generating systems.

The susceptibility of eggs to damage mediated by oxygenderived molecules was assessed by measuring the levels of several antioxidant scavenger enzymes. Ova contained only a moderate amount of SOD $(0.74 \mathrm{U} / \mathrm{mg}$ of protein). The possible importance of intraparasitic peroxidases in determining oxidant sensitivity was examined by determining the levels of endogenous catalase and GPO. Whereas catalase was not detected in egg extracts and live eggs failed to degrade $\mathrm{H}_{2} \mathrm{O}_{2}, S$. mansoni ova contained a high level of GPO activity $(8.6 \mathrm{U} / \mathrm{mg})$. An important functional role for GPO compared with catalase as a biologic defense mechanism has been noted in other studies of oxidant-mediated membrane damage. Lipid peroxidation of membranes mediated by low and physiologic levels of $\mathrm{H}_{2} \mathrm{O}_{2}$ was inhibited by GPO but not by catalase (50), a finding consistent with the observation that the $K_{\mathrm{m}}$ of GPO for $\mathrm{H}_{2} \mathrm{O}_{2}$ is significantly lower than the value for catalase $(51,52)$. Further elucidation of the role of these mechanisms in egg damage induced by oxygen-derived molecules will require characterization of $S$. mansoni egg GPO, assessment of parasite glutathione metabolism, and measurements of intraparasitic $\mathrm{H}_{2} \mathrm{O}_{2}$ and $\mathrm{OH}^{\circ}$.

\section{Acknowledgments}

The authors thank Pierre A. S. Peters and Shereif Khalil for their expert technical assistance.

This work was supported by a Research Career Development Award from the Rockefeller Foundation (Dr. Kazura) and grants from the Edna McConnell Clark Foundation and U.S. Public Health Service (No. 15351).

\section{References}

1. Henson, P. M. 1971. Interaction of cells with immune complexes: adherence, release of constituents, and tissue injury. J. Exp. Med. 134: $114 \mathrm{~s}-115 \mathrm{~s}$.
2. Vadas, M. A., J. R. David, A. E. Butterworth, N. T. Pisani, and T. A. Siongok. 1979. A new method for the purification of human eosinophils and neutrophils, and a comparison of the ability of these cells to damage schistosomula of Schistosoma mansoni. J. Immunol. 122:1228-1236.

3. Bass, D. A., and P. Szejda. 1979. Eosinophils versus neutrophils in host defense. Killing of newborn larvae of Trichinella spiralis by human granulocytes in vitro. J. Clin. Invest. 64:1415-1422.

4. Kazura, J. W., M. M. Fanning, J. T. Blumer, and A. A. F. Mahmoud. 1981. Role of cell-generated hydrogen peroxide in granulocyte-mediated killing of schistosomula of Schistosoma mansoni in vitro. J. Clin. Invest. 67:93-102.

5. Anwar, A. R. E., S. R. Smithers, and A. B. Kay. 1979. Killing of schistosomula of Schistosoma mansoni coated with antibody and/ or complement by human leukocytes in vitro: requirement for complement in preferential killing by eosinophils. J. Immunol. 122:628637.

6. Dean, D. A., R. Wistar, and K. D. Murrell. 1974. Combined in vitro effects of rat antibody and neutrophilic leukocytes on schistosomula of Schistosoma mansoni. Am. J. Trop. Med. Hyg. 23:420-428.

7. James, S. L., and D. G. Colley. 1978. Eosinophil-mediated destruction of Schistosoma mansoni eggs. J. Reticuloendothel. Soc. 20: 359-374.

8. Olds, G. R., and A. A. F. Mahmoud. 1980. Role of host granulomatous response in murine schistosomiasis mansoni: eosinophilmediated destruction of eggs. J. Clin. Invest. 66:1191-1199.

9. Warren, K. S. 1972. The immunopathogenesis of schistosomiasis: a multi-disciplinary approach. Trans. R. Soc. Trop. Med. Hyg. 66: 417-437.

10. Goldfine, H. 1972. Comparative aspects of bacterial lipids. $A d v$. Microb. Physiol. 8:1-58.

11. Samuelson, J. C., J. P. Caulfield, and J. R. David. 1980. Schistosoma mansoni: post-transformational changes in schistosomula grown in vitro and in mice. Exp. Parasitol. 50:369-383.

12. Stenger, R. J., K. S. Warren, and E. A. Johnson. 1967. An ultrastructural study of hepatic granulomas and schistosome egg shells in murine hepatosplenic schistosomiasis mansoni. Exp. Mol. Pathol. 7:116-132.

13. Race, G. J., J. H. Martin, D. V. Moore, and J. E. Larsh, Jr. 1971. Scanning and transmission electron microscopy of Schistosoma mansoni eggs, cercariae, and adults. Am. J. Trop. Med. Hyg. 20:914924.

14. Seed, J. L., and J. L. Bennett. 1980. Schistosoma mansoni: phenol oxidase's role in egg shell formation. Exp. Parasitol. 49:430441.

15. Hang, L. M., K. S. Warren, and D. L. Boros. 1974. Schistosoma mansoni: antigenic secretions and the etiology of egg granulomas in mice. Exp. Parasitol. 35:288-298.

16. Kloetzel, K. 1968. A collagenase-like substance produced by eggs of Schistosoma mansoni. J. Parasitol. 54:177-178.

17. deBrito, P. A., J. W. Kazura, and A. A. F. Mahmoud. 1984. Host granulomatous response in schistosomiasis mansoni: antibody and cell-mediated damage of parasite eggs in vitro. J. Clin. Invest. 74: 1715-1723.

18. Peters, P. A., and K. S. Warren. 1969. A rapid method of infecting mice and other laboratory animals with Schistosoma mansoni: subcutaneous infection. J. Parasitol. 55:558.

19. Brown, H. G., and J. I. Thomas. 1953. A method for isolating pure, viable schistosome eggs from host tissues. J. Parasitol. 49:371374.

20. Pellegrino, J., C. A. Olivira, J. Faria, and A. S. Cunha. 1962. New approach to the screening of drugs in experimental schistosomiasis mansoni in mice. Am. J. Trop. Med. Hyg. 11:201-215.

21. Boyum, A. 1968. Separation of leukocytes from blood and bone marrow. Scand. J. Clin. Lab. Invest. 21(Suppl. 97):77-90.

22. Kazura, J. W., and M. Aikawa. 1980. Host defense mechanisms against Trichinella spiralis infection in the mouse: eosinophil-mediated destruction of newborn larvae in vitro. J. Immunol. 124:355-361. 
23. Babior, B. M., J. T. Curnutte, and B. J. McMurrich. 1973. Biologic defense mechanisms: The production by leukocytes of superoxide, a potent bactericidal agent. J. Clin. Invest. 52:421-425.

24. Babior, B. M., and H. J. Cohen. 1981. Measurement of neutrophil function: phagocytosis, degranulation, the respiratory burst and bacterial killing. In Methods in Hematology, Book 3. Leukocyte Function. M. J. Cline, editor. Churchill-Livingstone Co., New York. $1-38$.

25. Root, R. K., J. Metcalf, N. Oshino, and B. Chance. 1975. $\mathrm{H}_{2} \mathrm{O}_{2}$ release from human granulocytes during phagocytosis. I. Documentation, quantitation, and some regulating factors. J. Clin. Invest. 55:945955.

26. Sjternholm, R. L., and K. S. Warren. 1974. Schistosoma mansoni: utilization of exogenous metabolites by eggs in vitro. Exp. Parasitol. 36:222-232.

27. Kazura, J. W., and A. A. F. Mahmoud. 1981. Protective role of eosinophils: The schistosome egg granuloma. In Immunobiology of the Eosinophil, T. Yoshida and M. Torisu, editors. Elsevier Biomedical Press, New York. 383-395.

28. Baudhuin, P., H. Beaufay, Y. Rahman-Li, O. Z. Sellinger, R. Wattiaux, P. Jacques, and C. de Duve. 1964. Tissue fractionation studies. 17. Intracellular distribution of monoamine oxidase, aspartate aminotransferase, alanine aminotransferase, D-amino acid oxidase and catalase in rat liver tissue. Biochem. J. 193:265-276.

29. Klebanoff, S. J. 1967. Iodination of bacteria: a bactericidal mechanism. J. Exp. Med. 126:1053-1078.

30. Mahmoud, A. A. F., M. A. Mandel, K. S. Warren, and L. T. Webster, Jr. 1974. Niridazole. II. A potent long-acting suppressant of cellular hypersensitivity. J. Immunol. 114:279-283.

31. Tsan, M., K. H. Douglass, and P. A. McIntyre. 1977. Hydrogen peroxide production and killing of Staphylococcus aureus by human polymorphonuclear leukocytes. Blood. 49:437-444.

32. Rosen, H., and S. J. Klebanoff. 1979. Bactericidal activity of a superoxide anion-generating system. A model for the polymorphonuclear leukocyte. J. Exp. Med. 149:27-39.

33. Diamond, R. D., R. A. Clark, and C. C. Hardenschild. 1981. Damage to Candida albicans hyphae and pseudohyphae by the myeloperoxidase system and oxidative products of neutrophil metabolism in vitro. J. Clin. Invest. 66:908-917.

34. Simon, R. H., C. H. Scoggin, and D. Patterson. 1981. Hydrogen peroxide causes the fatal injury to human fibroblasts. J. Biol. Chem. 256:7181-7186.

35. Lowry, O. H., N. J. Rosebrough, A. L. Farr, and R. J. Randall. 1951. Protein measurements with the Folin phenol reagent. J. Biol. Chem. 193:265-275.

36. McCord, J. M., and I. Fridovich. 1969. Superoxide dismutase. An enzymatic function for erythrocuprein (hemocuprein). J. Biol. Chem. 244:6049-6053.

37. Hopkins, J., and G. R. Tudhope. 1973. Glutathione peroxidase in human red cells in health and disease. Br. J. Haematol. 25:563575.

38. Butterworth, A. E., D. L. Wassom, G. J. Gleich, D. A. Loegering, and J. R. David. 1979. Damage to schistosomula of Schistosoma mansoni induced directly by eosinophil major basic protein. J. Immunol. 122:221-229.

39. Glauert, A. M., R. C. Oliver, and K. J. I. Thorne. 1980. The interaction of human eosinophils and neutrophils with non-phagocytosable surfaces: A model for studying cell-mediated immunity in schistosomiasis. Parasitology. 80:525-537.

40. Caulfield, J., G. Korman, A. E. Butterworth, M. Hogan, and J. R. David. 1980. Partial and complete detachment of neutrophils and eosinophils from schistosomula: evidence for the establishment of a continuity between a fused and normal parasite membrane. J. Cell. Biol. 86:64-76.

41. Smith, M. 1977. The ultrastructural development of the schistosome egg granuloma in mice. Parasitology. 75:119-123.

42. Santoro, F., A. Prata, C. N. Castro, and A. Capron. 1980. Circulating antigens, immune complexes and C3d levels in human schistosomiasis. Relationship with Schistosoma mansoni egg output. Clin. Exp. Immunol. 43:219-225.

43. Santoro, F., A. Prata, A. E. Silva, and A. Capron. 1981. Correlation between circulating antigens detected by the radioimmunoprecipitation-polyethylene glycol assay (RIPEGA) and Clq-binding immune complex in human schistosomiasis. Am. J. Trop. Med. Hyg. 30:1020-1025.

44. Jandl, R. C., J. Andre-Schwartz, L. Borges-DuBois, R. S. Kipnes, B. J. McMurrich, and B. M. Babior. 1978. Termination of the respiratory burst in human neutrophils. J. Clin. Invest. 50:1176-1185.

45. Clark, R. A., and S. J. Klebanoff. 1977. Myeloperoxidase$\mathrm{H}_{2} \mathrm{O}_{2}$-halide system: cytotoxic effect on human blood leukocytes. Blood. 50:65-70.

46. Klebanoff, S. J. 1980. Oxygen metabolism and the toxic properties of phagocytes. Ann. Intern. Med. 93:480-489.

47. Babior, B. M. 1978. Oxygen-dependent microbial killing of phagocytes. N. Engl. J. Med. 298:659-668.

48. McCord, J. M., and E. D. Day. 1978. Superoxide-dependent production of hydroxyl radical catalyzed by iron-EDTA complex. FEBS (Fed. Eur. Biochem. Soc.) Lett. 86:139-142.

49. Ambruso, D. R., and R. B. Johnston, Jr. 1981. Lactoferrin enhances hydroxyl radical production by human neutrophils, neutrophil particulate fraction, and an enzymatic generating system. J. Clin. Invest. 67:352-360.

50. McCay, P. B., D. D. Gibson, K-L Fong, and K. R. Hornbrook. 1976. Effect of glutathione peroxidase activity on lipid peroxidation in biological membranes. Biochim. Biophys. Acta. 431:459-468.

51. Misra, H. P. 1974. Generation of superoxide free radical during autoxidation of thiols. J. Biol. Chem. 249:2151-2155.

52. Flohe, L., and I. Brand. 1969. Kinetics of glutathione peroxidase. Biochim. Biophys. Acta. 191:541-549. 